\title{
Eksistensi Tuhan Saat Wabah Covid 19 Melanda
}

\author{
Albertus Bernando Agung Hamonangan Situmorang a, 1 \\ ${ }^{a}$ Magister Filsafat STFT Widya Sasana Malang \\ 1 albertusmagnus0608@gmail.com
}

\section{A R T I C L E I N F O \\ Article History: \\ Submitted: 23 November 2021 \\ Revised: 15 January 2022 \\ Accepted: 20 January 2022 \\ Keywords: Covid-19 Pandemic; Suffering; Existence of God; Freedom; Mankind}

Kata-kata Kunci: Pandemi Covid-19; Penderitaan; Eksistensi Tuhan; Kebebasan; Umat Manusia

\section{DOI:}

https://doi.org/10.53396/media. $\underline{\mathrm{v} 3 \mathrm{i} 1.49}$

\section{Copyright (C) 2022, Author}

\begin{abstract}
:
The essay presents a philosophical discussion on the question of God's existence during the time of covid-19. Methodologically it is a qualitative study. The author develops his argument by studying some relevant literature on the topics. The literature study focuses on some concepts of western and easter philosophy regarding the root of human suffering. The result shows that the fact of suffering does not derive from God, but from the free will of human beings. In Buddhism suffering is thought of as dukkha that exists from the very beginning of human life. To be free from this dukkha, man must live the socalled liberating paths of truth. In the western concept, suffering has nothing to do with God, because God himself did not create or will the suffering. God only wants to be consistent with His creation, namely to give full freedom to the creatures.
\end{abstract}

\section{ABSTRAK:}

Tulisan ini menyajikan diskusi filosofis tentang masalah eksistensi Tuhan selama masa covid-19. Secara metodologis, ini merupakan sebuah penelitian kualitatif. Penulis mengembangkan argumennya dengan mempelajari beberapa literatur yang relevan tentang topik tersebut. Studi literatur berfokus pada beberapa konsep filsafat barat dan timur tentang akar penderitaan manusia. Hasilnya menunjukkan bahwa fakta penderitaan tidak berasal dari Tuhan, tetapi dari kehendak bebas manusia. Dalam agama Buddha, penderitaan dianggap sebagai dukkha yang sudah ada sejak awal kehidupan manusia. Untuk bebas dari dukkha ini, manusia harus menjalani apa yang disebut jalan kebenaran yang membebaskan. Dalam konsep barat, penderitaan tidak ada hubungannya dengan Tuhan, karena Tuhan sendiri tidak menciptakan atau menghendaki penderitaan. Tuhan hanya ingin konsisten dengan ciptaan-Nya, yaitu memberikan kebebasan penuh kepada makhluk.

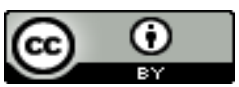

This work is licensed under a Creative Commons Attribution 4.0 International License

\section{Pendahuluan}

Manusia adalah mahluk yang bertanya. Apa pun yang berhadapan dengannya akan selalu dipertanyakan. ${ }^{1}$ Manusia sebagai makhluk yang memiliki akal budi akan menanyakan segala sesuatu peristiwa dalam hidupnya. Begitu juga pada masa pandemi ini, manusia akan bertanya di manakah Tuhan? Mengapa Tuhan mendatangkan bencana dalam hidup ini.

\footnotetext{
${ }^{1}$ Franz Magnis Suseno, Menalar Tuhan, 7 ed. (Yogyakarta: PT Kanisius, 2006), 17.
} 
Pertanyaan-pertanyaan inilah yang diajukan oleh manusia. Manusia tidak hanya berdiam diri dan menerima nasib begitu saja. Pertanyaan ini juga menjadi pertanyaan yang mendasar di tengah situasi pandemi.

Virus covid 19 terdeteksi pertama kali di kota Wuhan. Pada penghujung tahun 2019, jenis virus ini diketahui oleh masyarakat luas dan pada Maret 2020 telah menyebar hampir ke seluruh negara-negara. Virus ini telah mengakibatkan 178 juta kasus dan 3,9 juta mengalami kematian. ${ }^{2}$ Informasi pada 24 November 2021 mencatat bahwa pasien terinfeksi corona di dunia adalah 258.164.425 kasus dengan 5.166.192 kematian (CFR 2,0\%) di 204 negara terjangkit dan 151 negara transmisi komunitas. ${ }^{3}$ Data-data angka ini mengatakan bahwa pandemi menyebabkan ancaman bagi eksistensi. Mereka yang terpapar mengalami penderitaan yang berkelanjutan dalam hidup. Selain terisolasi, mereka juga tidak dapat bekerja sebagaimana biasanya.

Fakta penderitaan tak bisa dipungkiri, seperti kematian, penuhnya rumah sakit, kelaparan, pengangguran, tingkat kriminal semakin meningkat. Belum lagi adanya berbagai bencana alam yang mengakibatkan penderitaan orang. Berhadapan dengan penderitaan, pertanyaan fundamental yang diajukan adalah mengapa terjadi penderitaan? Dari mana penderitaan itu berasal? Lebih lagi manusia bertanya: Apakah Tuhan menghendaki penderitaan? Di manakah Tuhan yang Maha kuasa, Maha baik dan Maha adil saat wabah virus corona ini menyebabkan penderitaan yang amat mendalam?

Magis Suseno menyatakan bahwa penderitaan merupakan masalah malum morale sebab berhubungan dengan tidakberesan objektif yang ditemui di alam. ${ }^{4}$ Valentinus Saeng juga mengutarakan bawa secara inheren konsep penderitaan mencakup dua hal, yaitu dimensi batiniah dan dimensi fisik penderitaan. Dimensi fisik mengacu pada rasa sakit secara badani, misalkan nyeri karena luka. Dimensi rohani merujuk pada rasa khawatir, cemas, gelisah, galau, gundah-gulana yang membebani pikiran dan kesadaran seseorang. ${ }^{5}$ Pierre Teilhard de Chardin memandang penderitaan dari sudut evolusionis. Ia mengatakan bahwa penderitaan ada, sebab Allah menciptakan dunia yang evolutif. ${ }^{6}$ Dari perspektif evolusi, penderitaan itu merupakan sebab-akibat. Allah menciptakan dunia, maka akibatnya dunia mengalami penderitaan.

Leibniz juga mengutarakan bahwa penderitaan itu suatu dinamika yang dapat diputus sekaligus tidak dapat juga diputus. Jenis penderitaan yang diakibatkan oleh keburukan fisik seperti tubuh terasa sakit karena adanya penyakit, dapat diatasi dengan

\footnotetext{
2 Britt Yip and Valeria Perasso, “Asal Covid-19: Apakah kita perlu tahu dari mana asal virus corona ini?," $B$ B C News Indonesia, 2021, https:/ / www.bbc.com/indonesia/dunia-57590872.

${ }^{3}$ Dwi Annisa, "Situasi Terkini Perkembangan Coronavirus Disease (COVID-19) 25 November 2021," Infeksi Emerging:Media Informasi Resmi Terkini Penyakit Infeksi Emerging, 2021, https://covid19.kemkes.go.id/situasi-infeksi-emerging/situasi-terkini-perkembangancoronavirus-disease-covid-19-25-november-2021.

4 Suseno, Menalar Tuhan, 217.

5 Valentinus Saeng, "Hakikat Penderitaansebuah Tinjauan Filosofis," in Di Mana Letak Kebahagiaan?, ed. oleh Edison R.L. TinambunanKristoforus Bala,Vol 24 (Malang: STFT Widya Sasana, 2014), 128, http:/ /eprosiding. stftws. ac. id/ index. php/ serifilsafat/ article/ view/129/ 100.

${ }^{6}$ Elvin Atmaja Hidayat, "Iman Di Tengah Penderitaan : Suatu Inspirasi Teologis-Biblis Kristiani," Faculty of Philosophy Parahyangan Catholic University Bandung, Indonesia 32, 3, 201(2016): 287.
} 
menjaga pola hidup yang sehat, serta menghindari diri dari potensi yang membahayakan keselamatan diri. ${ }^{7}$

Dalam uraian ini, penulis hendak menguraikan jawaban filosofis atas pertanyaanpertanyaan fundamental sehubungan dengan fakta penderitaan dan keberadaan Tuhan di tengah penderitaan manusia, secara khusus penderitaan di masa pandemi. Metode penelitian menggunakan kualitatif deskripsi. Teknik analisis data yang digunakan dalam penelitian ini adalah analisis studi kepustakaan. Penulis dalam menjawab rumusan masalah akan menggunakan pemikiran Barat dan Timur.

\section{Tuhan Dan Manusia Dalam Konsep Barat Dan Timur}

Tuhan dalam dunia barat dipandang sebagai Sang Pencipta segala sesuatu, Mahakuasa dan Maha baik. Tuhan menurut orang yang beragama adalah sang pencipta yang abadi. Seperti yang diungkapkan Aquinas, Tuhan-pencipta sebagai landasan eksistensial bagi seluruh alam semesta. Dalam agama Yahudi, Kristen, dan Islam, Tuhan yang satu ini secara tradisional dipahami sebagai Mahakuasa.

Dalam pandangan Whitehead, Tuhan dimengerti sebagai prinsip limitasi yang memberi batas pada perwujudan nilai-nilai posibilitas. Tuhan berfungsi sebagai prinsip konkresi, yang menata posibilitas-posibilitas yang ada sehingga memungkinkannya efektif dalam proses menjadi suatu satuan aktual. ${ }^{8}$ Tuhan merupakan entitas aktual. Tuhan adalah wujud aktual dengan wujud-wujud aktual lainnya. Tuhan sebagai suatu entitas aktual, tidaklah pelaku dalam alam semesta melainkan partisipan, walaupun keberadaan ontologis-Nya menonjol serta peran-Nya cukup menentukan dibanding dengan wujud entitas aktual yang lain. Tuhan adalah Maha baik. Kebaikan Tuhan adalah kemurnian yang absolut. Tuhan selalu menghendaki yang terbaik. Dalam lingkup moral, ketika para kaum beragama menyatakan bahwa Tuhan itu baik, yang mereka maksudkan adalah Tuhan yang berpikir, berkehendak, dan bertindak dengan kebaikan. Dengan demikian Tuhan itu bersifat pribadi. Keberadaan Tuhan sebagai suatu entitas aktual di dalam solidaritas dengan entitas aktual yang lain mengandaikan relasi intersubjektivitas yang aktif. ${ }^{9}$

Dalam Hinduisme Brahmavidya digambarkan sebagai Tuhan. Eksistensi mutlak Brahman berada dalam tiga bentuk yakni Brahma, Vishnu, dan Shiva. Brahman ini sebagai pencipta, Vishnu sebagai pemelihara, dan Shiva pembawa kebinasaan dan kehidupan. ${ }^{10}$ Ketiga konsep ini menjadi penggerak atau pemberi arah dalam kehidupan manusia. I Ketut Bantas mengungkapkan bahwa pemahaman tentang Tuhan merupakan hal yang sangat penting dan paling perlu karena dengan mengenal Tuhan dengan mendalam dan benar

\footnotetext{
7 Hidayat, 286.

${ }^{8}$ Agustinus Nicolaus Yokit, "Konsep Tuhan dan Agama Menurut Alfred North Whitehead," Media (Jurnal Filsafat dan Teologi) 3, no. 2 (2021): 117, https:/ / doi.org/10.53396/media. v3i2.37.

${ }_{9}^{9}$ Eka Budianta Franz Dahler, Pijar Peradaban Manusia Denyut Harapan Evolusi (Yogyakarta: PT Kanisius, 2000), 120.

${ }^{10}$ Franz Dahler, 144.
} 
menjadi jalan bagi manusia kepada jalan kesempurnaan yakni sampai kepada moksa atau nirwana. ${ }^{11}$

Dalam upanisad Tuhan disebut Brahman. Brahman ini memiliki dua aspek yakni Saguna Brahman serta Nirguna Brahman. Nirguna memiliki posisi yang tinggi dibandingkan dengan Saguna Brahman. Dalam wujud Nirguna Tuhan dilukiskan dengan kata, tidak memiliki sifat, serta tidak berwujud. Dalam Nirguna Konsep Tuhan diungkapkan dengan istilah netineti atau "bukan ini, bukan juga itu". ${ }^{12}$ Dalam Saguna konsep Tuhan dihadirkan dengan sifat dan wujud-wujud tertentu di dunia ini. ${ }^{13}$

Pemahaman Tuhan di dunia Barat dan Timur memiliki makna dan konsep tersendiri. Dalam dunia Barat Tuhan lebih kepada yang Maha Tinggi dan berkuasa. Sedangkan, dalam dunia Timur Tuhan digambarkan atau dijelaskan dengan keadaan atau melalui alam semesta. Manusia yang berada di dunia akan selalu bertanya mengenai eksistensi dirinya. Dalam mengungkapkan eksistensinya manusia akan bertanya mengenai dirinya, keberadaannya, dan dunianya. Bertanya menjadi hal yang esensial dalam keberadaanya di dunia ini. Pertanyaan yang menyangkut tentang bumi, bulan, langit, serta Tuhan akan relevan jika dikaitkan dengan manusia. Lalu siapakah manusia itu?

Para filsus pra-Sokratik berpendapat bahwa manusia mengungkapkan kediriannya saat hidup sesuai dengan tata hukum alam. ${ }^{14}$ Artinya, manusia adalah yang berelasi dengan alam atau lingkungannya. Manusia yang segala pikiran dan tindakannya tidak bertentangan dengan alam. Terjadi harmoni yang dinamis antara manusia dan alam. Pada abad pertengahan, pertanyaan tentang siapakah manusia masih kontekstual. Pada masa ini pendekatan mereka tentang manusia tidak berpusat pada alam, tetapi berpusat pada keyakinan religius. Ajaran-ajaran pada masa ini berfokus pada hubungan manusia dengan Sang Pencipta. Pengertian seperti ini menjadikan manusia tak berdaya di hadapan yang Mahakuasa. Oleh karena itu, agar selamat hendaknya menjalin hubungan yang baik dengan Tuhan. Di tengah kondisi pandemi ini, manusia hidup dalam ketidakpastian, kekhawatiran dan ketakutan. Sehingga pada masa-masa ini pencarian makna sangat penting.

Whitehead menyatakan bahwa hidup manusia adalah sebuah proses yang menjadi terus-menerus. Manusia yang hidup dalam suatu proses ini memiliki kebebasan dalam dirinya. Kebebasan ini merupakan bagian mendasar dari keberadaan setiap manusia yang menampakkan aspek ketaatannya demi mencapai hal yang menyangkut keberlangsungan hidupnya. Manusia mempunyai kemampuan untuk memutuskan isi kesadarannya sendiri dan juga memberi makna atas apa yang sementara dialaminya pun apa yang menyangkut masa depannya. ${ }^{15}$ Pengertian kebebasan juga terkait dengan kesanggupan manusia memilih dan menentukan diri. Berhadapan dengan pilihan-pilihan manusia harus mengambil keputusan. Namun tidak jarang dalam mengambil keputusan

${ }^{11}$ I Ketut Bantas, “Tuhan Yang Maha Esa,” Angewandte Chemie International Edition, 6(11), 951-952., 2011, 151.

12 Gd Arya Krishna Duta dan Putra Nengah Sukmantara Tuboeh, "Filsafat Ketuhanan Dalam Kena Upanisad," Vidya Darśan Jurnal Mahasiswa Filsafat Hindu 2, no. 1 (2020): 67.

13 Tuboeh, 67.

${ }^{14}$ Kasdin Sihotang, Filsafat Manusia Jendela Menyingkap Humanisme (Yogyakarta: PT Kanisius, 2018$), 21$.

${ }^{15}$ Antonis Baju Nujartanto, "Menelaah Makna Kebebasan Individual Berhadapan dengan Protokol Kesehatan Covid 19," Media (Jurnal Filsafat dan Teologi) 3, no. 2 (2021): 163, https:/ / doi.org/10.53396/media.v3i2.38. 
manusia kerap salah memutuskan. Manusia dengan kebebasannya memilih yang berdampak buruk dengan sesama atau orang di sekitarnya. Sehingga yang terjadi adalah ketidakharmonisan dalam kehidupan.

Dalam filsafat Buddha, manusia itu hidup dalam empat jalan kebenaran. Namun dari keempat kebenaran itu, hidup yang biasa dialami manusia adalah duhkha atau hidup yang tidak memuaskan. Buddha melihat bahwa duhkha ini mucul karena ketidaktahuan eksistensi. Namun untuk menghilangkan duhkha ini, delapan jalan yang harus dihayati, yakni berpandangan benar dan bermaksud sehat, praktik moral (berbicara benar, bertindak benar, dan mata pencaharian yang benar), dan praktik meditatif (usaha yang benar, rasa kepedulian, dan konsentrasi). ${ }^{16}$ Manusia diberi kebebasan untuk menghayati delapan jalan kebenaran. Jika ingin terbebas dari duhkha, manusia harus menghidupi delapan jalan ini. Jika tidak, manusia akan berada dalam tatanan duhkha.

Dalam dunia Timur ada tiga ciri utama atau bentuk kehidupan, yakni tidak kekal, penderitaan, semua kondisi adalah tanpa Aku dan tidak berinti. Semua bentuk tidak kekal mengungkapkan bahwa semua fenomena yang terkondisi adalah tidak kekal. Hidup manusia akan mengalami proses dan perubahan dari gerak ke arah usia tua, sakit, dan kematian. Semua bentuk adalah penderitaan ingin menyatakan bahwa penderitaan merupakan fenomena hidup yang paling mendasar dan tidak dapat dihindari. Setiap yang memiliki rupa ambil bagian dalam penderitaan. Sumber utamanya adalah hawa nafsu dan hal duniawi. Seluruh keadaan merupakan tanpa Aku dan tidak berinti maksudnya tidak ada jiwa yang permanen dan kekal. ${ }^{17}$

Dalam pemikiran Barat, manusia itu dilihat dalam tiga konsep yakni manusia secara ontologis, psikologis, dan dialogis. Secara ontologis manusia itu merupakan makhluk yang rasional dan individualitas. Artinya manusia adalah makhluk yang berpikir dan memiliki kodrat sebagai individu. Thomas Aquinas mengatakan bahwa pribadi adalah manusia yang nyata dan individual dalam segala keunikannya. ${ }^{18}$ Artinya, manusia merupakan pribadi yang memiliki esensi dan eksistensi, yakni kodrat, rasio, serta keunikan dan kebebasan. Sebab cara berada manusia berkaitan dengan cara manusia bertindak. Secara psikologis manusia itu diletakkan pada posisi psikis. Pemahaman psikologis ini diungkapkan oleh Rene Descartes dalam Cogito ergo sum (saya berpikir maka saya ada). ${ }^{19}$ Dalam ungkapan ini manusia itu diletakkan pada jiwanya. Kemampuan manusia untuk berpikir dan memutuskan menjadi bentuk keberadaannya di dunia ini. Sedangkan secara dialogis manusia itu digambarkan sebagai makhluk yang relasional. Manusia terbentuk karena adanya relasi yakni relasi jiwa dan badan, relasi individu dengan masyarakat. Mouner seorang filsuf barat mengungkapkan bahwa setiap keberadaan manusia di dunia ini dipanggil untuk melakukan sesuatu untuk dunianya, dipanggil untuk bertindak dan dipanggil untuk berkomunikasi. ${ }^{20}$

\footnotetext{
16 Donats Sermada, Filsafat Asia (Maumere-Flores: Ledalero, 2010), 278.

${ }_{17}$ Matius Ali, Filsafat Timur Sebuah Pengantar Hinduisme dan Buddhisme (Jakarta: Sanggar LUXOR, 2013), 14041.

18 Sihotang, Filsafat Manusia Jendela Menyingkap Humanisme.

19 Sihotang, 44.

20 Sihotang, 11.
} 
Manusia dalam dunia timur memiliki konsep dan pandangan yang berbeda. Manusia itu digambarkan dalam keberagaman, baik dalam cara hidup, agama, kebudayaan, maupun letak geografisnya. Manusia Timur memandang pribadi manusia lebih kepada kebersamaan dari pada individulitas. Jika dalam dunia Barat manusia itu berharga dan bernilai ketika dia bereksitensi dan berpikir secara rasional, maka dalam dunia Timur seseorang itu berharga jika melibatkan diri dalam kehidupan bersama secara tetap dan harmonis. Manusia dalam pemikiran Konfisius selalu menganggap dirinya sebagai pemikir asli tetapi meneruskan dari apa yang sudah ada. ${ }^{21}$ Sedangkan dalam konsep filsafat India, manusia itu dipandang sebagai persona yang memiliki topeng wajah. Topeng wajah ini akan digunakan dalam pentas seni, dan selama pentas seni berlangsung topeng itu tidak dapat dilepas. $^{22}$ Topeng itu akan selalu melekat hingga kematian dan hidup setelah kematian. Konsep manusia antara Barat dan Timur memiliki perbedaan. Jika dunia Barat lebih menekankan pencarian identitas manusia, maka dunia Timur lebih kepada aspek ada bersama orang lain atau relasi yang mendalam bersama dengan sesama.

\section{Tuhan Dan Penderitaan Dalam Konsep Barat Dan Timur}

Masalah ketuhanan berpangkal pada manusia. Apabila manusia sadar akan dirinya, ia akan melihat faktisitas, transendensi, dan kebutuhan untuk mengerti menjadi bagian dari wujud eksistensi manusia. Ketiga sifat ini menjadi penyebab persoalan mengenai ketuhanan. ${ }^{23}$ Kenyataan yang pertama kali disadari oleh manusia adalah fakta bahwa dirinya ada. Keberadaannya tampak di depan kesadarannya dan merupakan sifat hakiki manusia yang tidak mungkin ditolak. Inilah Faktisitas. Faktisitas adalah eksistensi selalu tampak di depan diri manusia sebagai yang ada. Tiap kesadaran bereksistensi bagi manusia merupakan kesadaran akan suatu eksistensi yang sudah ada. ${ }^{24}$ Sifat ini sangat menonjol. Hal ini dapat dilihat bahwa sifat bukan mempengaruhi eksistensi dari luar, sebagaimana halnya dengan suatu penentuan yang terjadi secara kebetulan dan ditambahkan pada hakikat manusia yang sudah terbentuk. Sifat itu dipengaruhi dari dalam diri manusia itu sendiri. Jika sifatnya baik, maka hidupnya juga akan baik. Sebaliknya, jika sifatnya buruk, maka hidupnya buruk. Jadi sifat-sifat manusia tidak dipengaruhi dari cara berada di dunia ini. Faktisitas ini berciri konstitutif dari dalam dan mengondisikan manusia untuk mengerti serta mempertanyakan. Siapakah manusia? Apakah arti kehidupan? Dalam konteks tersebut yang menjadi persoalan adalah: mengapa manusia sadar akan eksistensinya? Mungkinkah kesadaran ini merupakan suatu petunjuk bahwa adanya bersandar pada suatu realitas pencipta?

Demikianlah permenungan akan eksistensi yang membawa manusia pada sifatnya yang transenden. Modus utamanya adalah kebutuhan hakikinya untuk mengerti. Manusia sadar bahwa ia berada di antara berbagai pengada. Manusia sadar bahwa ia berbeda dengan orang lain. Sekaligus manusia sadar bahwa dirinya bukanlah barang yang tergeletak begitu saja di samping barang-barang lain. Kesadaran ini membuat keberadaannya tidak dapat direduksi dalam kerangka ruang dan waktu. Manusia secara hakiki memiliki karakter

\footnotetext{
${ }^{21}$ Konrad Kebung, Filsafat Berpikir Orang Timur (Jakarta: Prestasi Pustaka, n.d.), 161.

22 Kebung, 59.

${ }^{23}$ Lois Leahy, Manusia Sebagai Misteri: Sintesa Filosofis tentang Mahluk Paradoksal (Jakarta: Gramedia, 1992), 40.

${ }^{24}$ Leahy, 38.
} 
transendensi. Pertanyaannya adalah sampai di mana jangkauan transendensi manusia itu? Akhirnya mengutip pernyataan Paul Ricoeur, "masalah tentang Tuhan selalu batas-batas terakhir manusia dan pada akhirnya adalah masalah tentang arti transendensi" 25

Di balik ini semua, manusia tidak pernah lepas dari penderitaan. Manusia yang mengakui dan percaya kepada Tuhan tetap mengalami penderitaan dalam hidupnya. Dalam konsep Timur penderitaan itu berasal dari manusia itu sendiri karena tidak hidup dalam kebajikan. Dalam konsep Hinduisme, penyebab penderitaan dibagi dalam dua hal yakni Artha dan Kama. Artha merupakan sikap dalam kepemilikan barang material yang diperoleh dengan cara curang demi kenikmatan tubuh dan kepuasan sesaat. Sedangkan Kama merupakan penderitaan yang berasal dari kenikmatan dan cinta sesaat. ${ }^{26}$ Konfusius mengungkapkan bahwa penderitaan itu berasal dari kecemasan, keraguan, kedegilan, kekacauan pikiran, dan ketakutan manusia. Sedangkan dalam konsep Barat penderitaan itu merupakan pilihan bebas dari manusia. Manusia bebas untuk menentukkan mana yang terbaik dan berguna dalam hidupnya. Jika manusia ingin lepas dari penderitaan, maka manusia hendaknya memilih hal yang dapat membawanya kepada kebahagiaan. Namun jika manusia hanya ingin mementingkan ego dan nafsunya, maka akan membawa kepada penderitaan.

\section{Covid-19 Tanda Tidak Adanya Allah?}

Merebaknya virus covid-19 ini merupakan penderitaan yang amat mendalam bagi manusia. Fakta penderitaan merupakan salah satu tema yang menjadi topik pembahasan dalam Filsafat Ketuhanan. Penyebab penderitaan di dunia dibagi menjadi dua, yakni penderitaan karena kejahatan moral dan penderitaan karena kejahatan alamiah. ${ }^{27}$ Secara moral, kejahatan itu muncul dari sekelompok orang atau pribadi yang bertindak secara sadar dan bebas namun tidak sesuai dengan hukum moral. Salah satu bentuk kejahatan moral adalah kurangnya kepedulian terhadap penderitaan orang lain. Penderitaan secara alamiah disebabkan oleh determinasi alamiah, seperti cacat bawaan, gempa bumi, banjir, tsunami dan lain-lain. Tulisan klasik dari Epikuros yang usianya lebih dari 2000 tahun lalu menyarikan problem penderitaan dan adanya Allah ini dengan sangat baik. Epikuros menyatakan bahwa ada empat kemungkinan: Tuhan ingin melenyapkan kejahatan tetapi tidak bisa; atau Tuhan mampu meniadakan kejahatan namun Ia menolak; atau Tuhan tidak bisa dan tidak mau meniadakan kejahatan; atau Dia mampu dan bisa meniadakan kejahatan. ${ }^{28}$ Kemungkinan pertama tidak sesuai dan bertentangan pada hakikat Allah yang Maha baik serta Maha adil. Kemungkinan keempat tampak berlawanan pada realitas dunia yang dipenuhi kejahatan dan penderitaan. Secara sangat sederhana dilema dapat dirumuskan sebagai berikut: kejahatan dan penderitaan atau tidak dapat atau tidak mau dihindari oleh Allah. Apabila diterima yang pertama, berarti Allah tidak mahakuasa, dan itu berarti sama dengan tidak ada Allah, sedangkan apabila diterima yang kedua, Allah tidak maha baik dan maha adil, dan itu pun tidak dapat diterima oleh orang beriman.

\footnotetext{
25 Leahy, 41.

${ }^{26}$ Kebung, Filsafat Berpikir Orang Timur, 66-67.

${ }^{27}$ Leahy, Manusia Sebagai Misteri: Sintesa Filosofis tentang Mahluk Paradoksal, 200.

${ }^{28}$ K. Bertens, Ringkasan Sejarah Filsafat, Yogyakarta: Kanisius, 1975, hlm 17.
} 
Secara sederhana, kita dapat mengatakan: Jika ada kejahatan, maka Tuhan tidak ada. Sanggahan ini dinyatakan pada setiap tingkatan pemikiran manusia. Dalam pemikiran biasa sanggahan itu berbunyi: Jika Tuhan baik, pasti tidak akan ada perang, penderitaan, siksaan, dan kematian. Thomas Aquinas menjelaskan dengan alur pemahaman terperinci: Jika Allah ada, maka kejahatan tidak akan ditemukan. Namun dalam dunia real kejahatan itu ada. Dengan demikian tidak ada Allah. ${ }^{29}$ Konsep ini menggas pemahaman mengenai Allah sebagai ada yang tak terhingga. Allah sebagai yang baik, tidak akan mengizinkan adanya kejahatan, dan sebagai Yang Mahakuasa mampu menghalanginya.

Dalam sebuah naskah klasik, Epikuros menyatakan bahwa Allah mau meniadakan kejahatan tetapi tidak, atau Ia bisa namun tidak dapat. Jika Allah bersedia namun tidak dapat, maka Ia tidak berkekuatan. Namun sifat ini tidak ada dalam diri Allah. Sehingga yang tepat bagi Allah ialah Ia mau dan mampu. Lalu dari mana penderitaan akibat covid-19, jika Tuhan dapat dan mampu meniadakan penderitaan. ${ }^{30}$ Bukti keberadaan Allah tidak bernilai, sebab bukti-bukti yang ada tidak dapat menyelesaikan atau menjawab sanggahan dari eksistensi penderitaan. Dapat disimpulkan bahwa covid-19 bukan berarti tanda tidak adanya Allah di muka bumi. Munculnya covid merupakan tanda bahwa Tuhan itu merupakan realitas yang tidak dapat diungkapkan manusia lewat ilmu pengetahuan. Bencana Covid ini menjadi salah satu cara Tuhan untuk menyadarkan manusia bahwa dalam situasi dan kondisi apapun Tuhan selalu hadir dan menemani manusia sejauh manusia percaya dan mengakui keberadaanNya.

\section{Tuhan Dan Penderitaan}

Kata penderitaan di dunia ini memiliki beragam arti. Penderitaan bukanlah sekedar pengalaman yang keluar dari hati manusia yang amburadul, melainkan inti keras yang berasal dari perbuatan-perbuatan kejahatan. Mengalami penderitaan tidak melulu karena mengikuti kelemahan, emosi dan nafsu. Orang beriman akan bertanya tentang adanya penderitaan. Sebab eksisten penderitaan terkadang berkontradiksi dengan keyakinan iman bahwa Tuhan adalah Yang Mahasuci dan membenci penderitaan yang diakibatkan kejahatan.

Manusia memiliki kebebasan untuk mengaktualisasikan dirinya. Keberadaan penderitaan tidak bisa menjadi argumen untuk menyatakan bahwa Allah tidak ada. Penyebab penderitaan adalah manusia sendiri. Manusia diciptakan dengan akal budi dan menganugerahkan kepadanya kemampuan untuk menjawab cinta kasih Allah dengan bebas. Sesungguhnya Allah tidak pernah menginginkan kejahatan terjadi. ${ }^{31}$

Dalam konsep Buddha ada lima penyebab penderitaan atau duhkha. Dalam Yoga Sutra disebutkan kelima penyebab penderitaan itu adalah kebodohan, keakuan, keterikatan, kebencian, ketakutan dan kematian. ${ }^{32}$ Penderitaan ini tidaklah bersifat permanen. Manusia dapat bebas dari penderitaan sejauh ia mau menjalankan delapan jalan kebahagiaan. Namun,

\footnotetext{
${ }^{29}$ Leahy, Manusia Sebagai Misteri: Sintesa Filosofis tentang Mahluk Paradoksal, 270.

${ }^{30}$ Leahy, 270.

${ }^{31}$ Franz Magnis Suseno, Menalar Tuhan, Yogyakarta: Kanisius, 2006, hlm 219.

32 Made Joniarta, "Duhkha Dalam Chandogya Upanisad Dan Cara Mengatasinya," Jurnal Yoga Dan Kesehatan 1, no. 2 (2020): 183, https:/ / doi.org/10.25078/jyk.v1i2.1582.
} 
di balik itu semua Duhkha memiliki akarnya dalam ketidakpuasan. Duhkha diartikan sebagai ketidaksanggupan untuk hidup dengan baik. ${ }^{33}$ Dengan demikian penderitaan itu tidak ada hubungannya dengan Tuhan. Penderitaan merupakan sebab dari kebebasan manusia.

\section{Eksistensi Tuhan Saat Virus Corona Menyerang Dunia}

Jika Allah itu Maha Baik dan Maha Kuasa, mengapa harus ada penderitaan akibat Covid-19? Apakah wabah ini berasal dari Tuhan? Di mana Tuhan di saat dunia menghadapi pandemi Covid-19? Penderitaan akibat virus corona ini dapat juga dipandang sebagai hal yang baik bagi kehidupan manusia. Leibniz menyatakan: Dunia yang disertai penderitaan akan menjadi lebih baik dibandingkan tanpa penderitaan. ${ }^{34}$ Pendapat ini ingin mengatakan bahwa Allah tidak menciptakan dunia tanpa ketidaksempurnaan dan penderitaan. Tentu anggapan ini memang ada benarnya juga. Cacat, keburukan dan penderitaan saling terhubung dengan keterbatasan dan ketidaksempurnaan yang esensial bagi seluruh ciptaan. Namun ketidaksempurnaan tidak menjadi halangan bagi manusia untuk mencapai kebaikan tertinggi dan kebahagiaan tertinggi. Keburukan adalah kebaikan yang tidak tercapai, padahal seharusnya tercapai. Bagi makhluk perasa, kekurangan ini diartikan ke dalam kesanggupan untuk menderita. Semakin bertumbuh unsur kesadaran dalam makhlukmakhluk hidup, semakin hebat kesanggupannya untuk menderita. ${ }^{35}$ Manusia yang mengalami penderitaan tidaklah berjalan sendirian. Tuhan sebagai satuan aktual turut mengalami dan merasakan setiap peristiwa yang ada dalam realitas kehidupan manusia maupun alam. Tuhan selalu ada dan tinggal bersama manusia. Ia turut merasakan apa yang dirasakan manusia. Whitehead dalam permenungannya menggambarkan Tuhan sebagai the great companion -the fellow-sufferer who understands (sahabat karib, sesama penderita yang dapat mengerti). ${ }^{36}$ Dalam penderitaan yang dialami manusia, Tuhan selalu hadir sebagai sahabat dalam hidup manusia. Ia membiarkan diri-Nya dialami oleh setiap satuan aktual.

Kelompok teisme memandang Tuhan sebagai Yang Mahakuasa, Mahatahu dan Maha sempurna, walaupun di dunia ini ada penderitaan. Mackie seorang filsuf Australia mengatakan bahwa tidak ada pertentangan anatar "eksistensi Tuhan sebagai Yang Kuasa, Maha tahu, dan yang sempurna," dengan "keberadaan kejahatan di muka bumi ini. ${ }^{37}$ Tetapi, ketika menyadari bahwa rupa dari kebaikan akan melenyapkan kejahatan, dan sosok dari Allah tidak mempunyai batasan untuk melakukan apa pun, maka saat itu terjadi kontradiksi. Lebih lanjut, Journet mengalami kesulitan untuk menghubungkan dengan tepat hubungan antara masalah kejahatan dengan keadilan Tuhan, dan ia mengatakan itu suatu misteri: "Jika Tuhan tidak ada, dari mana asal kebaikan? Jika keberadaan Tuhan sungguh nyata, lalu dari mana awal dari kejahatan? Jika Tuhan merupakan akar kebaikan, apakah Tuhan dapat

\footnotetext{
33 Sermada, Filsafat Asia, 313.

34 Suseno, Menalar Tuhan, 225.

${ }^{35}$ Leahy, Manusia Sebagai Misteri: Sintesa Filosofis tentang Mahluk Paradoksal, 273.

${ }^{36}$ Yokit, "Konsep Tuhan dan Agama Menurut Alfred North Whitehead," 178.

37 J. L. Mackie, The Miracle of Theism: Arguments for and Against the Existence of God (Oxford: Clarendon Press, 1982), 150.
} 
dikatakan akar kejahatan? Kejahatan ada dan Tuhan ada. Koeksistensi keduanya adalah suatu misteri." 38

Eksistensi manusia selaku makhluk hidup menjadi terbatas, lemah, dan terluka. Hal ini tidak bisa dipungkiri dalam diri manusia sebab garis hidup tidak terlepas dari kehausan, penuaan dan kematian. Dengan demikian, kemungkinan untuk menderita merupakan bagian dari kodrat manusia. Jika Allah tidak dapat menciptakan alam semesta beserta isinya tanpa ada peluang terjadinya keburukan, penderitaan dan dosa, itu artinya Allah tidak berkuasa.

Jika Allah berkeinginan menciptakan semesta seperti manusia, maka secara bebas manusia dapat menanggapi panggilan Allah. Allah tentu tidak akan campur tangan untuk mencegah keburukan, penderitaan, kejahatan dan dosa. Allah tidak mengehendakinya dan tidak mencegahnya, sebab Ia konsisten terhadap kehendak-Nya untuk menciptakan semesta seperti itu. ${ }^{39}$

Dalam ajaran Buddha menghayati jalan tengah dipandang secara jalan untuk terbebas dari penderitaan. Jala tengah dalam ajaran Buddha disebut Madhyamaka atau kekosongan. Kekosongan menunjuk pada eksistensi diri yang kosong dan permanensi bahwa setiap hal berhubungan satu sama lain dan senantiasa berubah. ${ }^{40}$ Dalam jalan tengah ini kekosongan bukan hanya mendeklarasikan tidak adanya permanensi dan eksistensi diri, tetapi juga menunjukkan kepenuhan eksistensi seperti yang dialami secara langsung dalam praktik pemusatan pikiran dan perhatian. Jalan tengah hidup dengan menghilangkan kecenderungan unutk memahami segala sesuatu sebagai eksistensi-eksistensi yang terpisah dan permanen, kekosongan yang bisa mengatasi kelekatan atau kelobaan yang melahirkan duhkha. Kekosongan ini bukan hanya dipahami, tetapi juga harus dipraktikkan di dalam hidup. Penderitaan dalam konsep buddha tidak melulu berdampak negatif melainkan juga memiliki sisi positif.

\section{Kesimpulan}

Tuhan adalah Sang Pencipta segala sesuatu, Maha kuasa dan Maha baik. Tuhan sebagai sang pencipta memberikan yang baik pada manusia. Tuhan selalu ada dan hadir bagi manusia. Tuhan adalah yang Maha baik yang memiliki kebaikan absolut. Tuhan selalu menghendaki yang terbaik. Tuhan selalu berpikir, berkehendak dan bertindak dengan kebaikan. Artinya bahwa keberadaan Tuhan sebagai suatu entitas aktual di dalam solidaritas dengan entitas aktual yang lain mengandaikan relasi yang intersubjektifitas yang aktif. Tuhan selalu menunjukkan eksistensi-Nya di dunia ini. Penderitaan yang ada di dunia ini bukanlah atas kehendak atau keinginan Tuhan.

Manusia yang selalu bertanya akan berusaha mencari asal dan sebab atas segala peristiwa kehidupan yang dialaminya. Manusia yang terdiri dan tubuh dan jiwa menunjukkan kesatuannya yang dalam membentuk dan mengaktualisasikan dirinya di dunia ini. Manusia pada hakikatnya adalah makhluk yang bebas. Kebebasan manusia menjadi salah satu cara untuk bereksistensi di dunia ini. Tujuan awal dari kebebasan yang dilakukan

\footnotetext{
${ }^{38}$ H. J. Mc Closkey, God and Evil (Netherlands: Martinus Nijhoff, 1974), 2.

39 Suseno, Menalar Tuhan, 226.

40 Sermada, Filsafat Asia, 410.
} 
manusia adalah untuk menyempurnakan diri. Pengertian kebebasan juga terkait dengan kesanggupan manusia untuk memilih dan menentukan diri. Untuk memilih merupakan kenyataan dalam kehidupan manusia. Saat dihadapkan dengan pilihan-pilihan manusia harus dapat mengambil keputusan. Namun tidak jarang dalam mengambil keputusan manusia kerap salah memutuskan. Manusia dengan kebebasannya memilih yang berdampak buruk dengan sesama atau orang di sekitarnya. Sehingga yang terjadi adalah ketidakharmonisan dalam kehidupan.

Penderitaan, Tuhan dan manusia menjadi satu kesatuan yang saling bertentangan. Penderitaan manusia menyebabkan eksistensi Tuhan menjadi kabur. Juga akibat penderitaan menyebabkan eksistensi manusia di dunia ini menjadi tidak aktual. Namun penderitaan itu tidaklah berasal dari Tuhan. Tuhan sama sekali tidak menginginkan penderitaan di bumi ini. Penderitaan pertama-tama berasal dari manusia itu sendiri. Manusia yang tidak menyadari setiap perbuatan dan tingkah lakunya menjadikan penderitaan itu terjadi. Allah tidak menginginkan penderitaan di muka bumi ini. Allah hanya menginginkan kedamaian dan kebahagiaan bagi manusia. Allah selalu mengusahakan yang terbaik bagi manusia.

\section{Kepustakaan}

Ali, Matius. Filsafat Timur Sebuah Pengantar Hinduisme dan Buddhisme. Jakarta: Sanggar LUXOR, 2013.

Annisa, Dwi. "Situasi Terkini Perkembangan Coronavirus Disease (COVID-19) 25 November 2021." Infeksi Emerging:Media Informasi Resmi Terkini Penyakit Infeksi Emerging, 2021. https://covid19.kemkes.go.id/situasi-infeksi-emerging/situasiterkini-perkembangan-coronavirus-disease-covid-19-25-november-2021.

Bantas, I Ketut. "Tuhan Yang Maha Esa." Angewandte Chemie International Edition, 6(11), 951-952., 2011, 1-51.

Closkey, H. J. Mc. God and Evil. Netherlands: Martinus Nijhoff, 1974.

Franz Dahler, Eka Budianta. Pijar Peradaban Manusia Denyut Harapan Evolusi. Yogyakarta: PT Kanisius, 2000.

Hidayat, Elvin Atmaja. "Iman Di Tengah Penderitaan: Suatu Inspirasi Teologis-Biblis Kristiani." Faculty of Philosophy Parahyangan Catholic University Bandung, Indonesia 32, 3, 201 (2016): 285-308.

Joniarta, Made. "Duhkha Dalam Chandogya Upanisad Dan Cara Mengatasinya." Jurnal Yoga Dan Kesehatan 1, no. 2 (2020): 179-89. https://doi.org/10.25078/jyk.v1i2.1582.

Kebung, Konrad. Filsafat Berpikir Orang Timur. Jakarta: Prestasi Pustaka, n.d.

Leahy, Lois. Manusia Sebagai Misteri: Sintesa Filosofis tentang Mahluk Paradoksal. Jakarta: Gramedia, 1992.

Mackie, J. L. The Miracle of Theism: Arguments for and Against the Existence of God. Oxford: Clarendon Press, 1982.

Nujartanto, Antonis Baju. "Menelaah Makna Kebebasan Individual Berhadapan dengan Protokol Kesehatan Covid 19." Media (Jurnal Filsafat dan Teologi) 3, no. 2 (2021): 159-72. https://doi.org/10.53396/media.v3i2.38.

Perasso, Britt Yip and Valeria. "Asal Covid-19: Apakah kita perlu tahu dari mana asal virus corona ini?" B B C News Indonesia. 2021. https://www.bbc.com/indonesia/dunia57590872. 
Saeng, Valentinus. "Hakikat Penderitaan Sebuah Tinjauan Filosofis." Di Mana Letak Kebahagiaan?, diedit oleh Edison R.L. TinambunanKristoforus Bala, Vol 24., 12746. Malang: STFT Widya 2014. http://eprosiding.stftws.ac.id/index.php/serifilsafat/article/ view/129/100.

Sermada, Donats. Filsafat Asia. Maumere-Flores: Ledalero, 2010.

Sihotang, Kasdin. Filsafat Manusia Jendela Menyingkap Humanisme. Yogyakarta: PT Kanisius, 2018.

Suseno, Franz Magnis. Menalar Tuhan. 7 ed. Yogyakarta: PT Kanisius, 2006.

Tuboeh, Gd Arya Krishna Duta dan PutraNengah Sukmantara. "Filsafat Ketuhanan Dalam Kena Upanisad.” Vidya Darśan Jurnal Mahasiswa Filsafat Hindu 2, no. 1 (2020): 6371.

Yokit, Agustinus Nicolaus. "Konsep Tuhan dan Agama Menurut Alfred North Whitehead." Media (Jurnal Filsafat dan Teologi) 3, no. 2 (2021): 173-84. https://doi.org/10.53396/media.v3i2.37. 